\title{
Focus
}

\section{Terug naar de Europese Traditie (?)}

W. van Vlastuin

Andreas Kinneging, De onzichtbare MAAT. Archeologie van goed en kwaad

(Amsterdam: Prometheus, 2020), 639 p., € 27,50 (ISBN 9789035138797).

Dit nummer van Theologia Reformata laat ons zien welke vragen er aan de orde zijn als we luisteren naar de Schrift. Elke tijd vraagt opnieuw om een oriëntatie op de cultuur om ons bewust te zijn van de hermeneutische beslissingen die we nemen in het luisteren naar de stem van de levende God zoals deze in het Woord tot ons komt.

In de doordenking van deze vragen is het van belang om een besef te hebben van onszelf en onze eigen culturele bepaaldheid en beperktheid. Om ons bewust te zijn van onze eigen culturele bepaaldheid is het nodig om het eigene van onze cultuur te zien in het licht van andere culturen en de historische plaats waar wij staan.

Hiermee is de relevantie van het voorliggende boek gegeven. Andreas Kinneging neemt ons mee door de ontwikkeling van de westerse cultuur. De grondvraag is steeds: hoe duiden wij de werkelijkheid? Ik geef eerst enkele hoofdlijnen van zijn boek door en daarna kom ik tot enkele overwegingen.

De inhoudsopgave van het boek zou weleens een aanwijzing kunnen zijn van de missie die achter het boek zit. Immers, bij de duiding van de westerse cultuur is het voorstelbaar om dit in historische zin te doen. Dan begin je met de oudste cultuurfase en volg je de loop van de geschiedenis. Kinneging heeft er bewust voor gekozen om dat niet te doen. Hij bespreekt eerst de Moderniteit (ik neem de hoofdletters van Kinneging in dit artikel over) en dan volgt de klassieke benadering, door hem de Europese Traditie genoemd.

Tijdens het lezen wordt het wel duidelijk waarom dit gebeurt. Kinneging is uiterst kritisch op onze cultuur. Hij laakt de beeldcultuur waardoor het vermogen tot abstractie verbleekt en de emoties de overhand krijgen. Ook is hij ongerust over het gebrek aan deugden, huwelijkstrouw en matigheid. Vooral de verplatting gaat hem aan het hart. Hij ziet in onze cultuur een aanval op de Europese Traditie, een tweede zondeval. Deze aanval is al enkele eeuwen 
gaande en breekt vooral sinds de jaren '60 van de vorige eeuw door. Kinneging wijst expliciet naar universiteiten waar de fundamentele vragen niet meer worden gesteld, maar waar de ideologie van de Moderniteit leidend is. We hebben inmiddels het gevoel dat we op de drempel van een nieuwe tijd staan. In deze nieuwe tijd gaan kostbare schatten van de Europese Traditie verloren. We zijn een zielloze cultuur geworden. Er is een algemeen gevoel in onze cultuur dat de oude tijden slecht waren, niet alleen omdat er toen zoveel ziektes waren, maar ook omdat vrouwen onderdrukt werden bijvoorbeeld. Deze radicale breuk met het verleden leidt tot grote problemen. De remedie voor de problemen in onze cultuur is een herneming van de klassieke duiding van de werkelijkheid.

\section{De Verlichting}

Zo komen wij bij het eerste deel van dit boek, de Moderniteit. De Moderniteit valt voor Kinneging uiteen in twee delen, namelijk de Verlichting en de Romantiek. Het algemene idee is dat in de Verlichting eindelijk de rede een plaats kreeg en dat we verlost werden van bijgeloof en domheid. De nadruk op de instrumentele rede leidde tot een verplatting van het wereldbeeld. We zouden alleen maar materie zijn. Het is niet verwonderlijk dat deze nieuwe kosmologie ook leidde tot een nieuwe mensvisie en een nieuwe moraal.

De nieuwe moraal kenmerkte zich door vrijheid en gelijkheid. De Verlichting rekende af met hiërarchie en stelde gelijkheid in de plaats daarvan. Zo kwam vrijheid in plaats van discipline. Vrijheid en gelijkheid werden onopgeefbare principes in de nieuwe tijd en ze kregen een religieuze lading. Dat betekent dat er niet over te discussiëren valt en dat er geen verdraagzaamheid is ten opzichte van andere uitgangspunten. Bovendien is er in de westerse wereld een sterke drang tot missie van de verlichtingswaarden over de hele wereld.

Waar gaat het om in het principe van vrijheid en gelijkheid? Mensen zijn vrij om te streven naar de bevrediging van hun oneindige begeerten. Volgens de verlichtingsmens zal de vervulling van deze begeerten tot geluk leiden. De zin van het leven is dat je doet waar je zin in hebt. Zo voeden wij onze kinderen ook op. Onze opleidingen zijn erop gericht om op een rationele wijze zo veel mogelijk begeerten te kunnen vervullen.

Zo is de homo-oeconomicus geboren en licht het vrijemarktdenken op. De samenleving is een sociaal contract van gelijke individuen die allemaal hun eigenbelang zoeken. De keerzijde van deze cultuur is de afbraak van gemeenschappen. Het leidt ook tot verdomming van de mensheid, omdat er niet meer wordt nagedacht over het wezen van de dingen, alleen over efficiëntie en effectiviteit. De verlichte mens is 'half god, half varken', omdat hij zichzelf het hoogste gezag toemeet en omdat hij geen diepere behoeften heeft dan 
materiële. Het nihilisme ligt hierin opgesloten. Waarom zou vrijwillige prostitutie een probleem zijn, vrijwillige gladiatorengevechten, vrijwillige euthanasie? Moderniteit leidt tot de 'morele idioot'.

\section{De Romantiek}

De Romantiek stelde de Verlichting onder kritiek. Kant en Rousseau zijn de vaders van de Romantiek. In de Romantiek ging het niet om de fenomenale wereld van de waarneming, maar om de transcendentale wereld die we alleen met ons gevoel kennen. De hedendaagse uitwerking van de Romantiek is kritisch over nutmaximalisatie, omdat dit leidt tot lage lonen, uitbuiting van de aarde, bio-industrie, klimaatcrisis, enzovoorts.

In plaats van de analytische gezindheid en de grootste kwantitatieve gemene deler kwam de aandacht voor het echte zelf. We moeten onszelf verwerkelijken. Deze grondhouding is kritisch naar traditie omdat traditie de zelfontplooiing in de weg staat. Volgens Kinneging is deze zoektocht naar ons authentieke zelf krankzinnig, omdat we ons echte zelf nooit zullen vinden. Vandaag kunnen we denken dat we bij ons diepste innerlijke gevoel zijn, maar morgen kan ons gevoel een andere kant op wijzen. We bestaan niet zonder anderen, zonder gemeenschap, zonder cultuur. De romantische gezindheid sluit ons ook af voor de ontvankelijkheid om van anderen te leren.

Onderwijl is de romantische gezindheid wel belangrijk in onze cultuur. Het betekent dat alles kan, zolang we de ander in zijn of haar waarde laten. $I k$ ben oké, jij bent oké van Thomas Harris waarvan 15 miljoen exemplaren over de toonbank gingen, is symptomatisch voor de Romantiek in onze tijd.

In de kunst betekent dit dat we zoeken naar de allerindividueelste expressie van de allerindividueelste emotie. In de opvoeding leidt Romantiek tot leerkrachten die de coach zijn van prinsen en prinsesjes, terwijl moraal problematisch wordt. Het enige dat overblijft is het principe om een ander niet te beschadigen. Je kunt uitgaan van jezelf, zolang de ander geen schade lijdt.

Kinneging behandelt in dit verband de visie op de liefde. De romantische benadering van de liefde sluit eigenlijk het krijgen van kinderen uit, omdat kinderen offers kosten. Maar ook zonder kinderen wordt de romantische seksualiteit een herhaling van zetten, zodat we er helemaal voor openliggen om er met een andere Ware vandoor te gaan.

Kinneging stelt ook pedofilie aan de orde. Hij signaleert dat Romantiek hier geen morele benadering hanteert, aangezien pedofilie wordt gezien als een persoonlijkheidsdeformatie. Dus is het verschijnsel pedofilie geen bewijs tegen de gedachte dat ieder zijn eigen verlangens moet realiseren, omdat pedofiele verlangens niet de eigenheid van iemands verlangens kunnen zijn.

Een andere belangrijke kwestie is de revolutionaire gezindheid van de 
Romantiek. De Romantiek idealiseert het verleden of heeft een utopisch idee over de toekomst. De Franse Revolutie is een voorbeeld waarin de Romantiek een greep naar de toekomst heeft gedaan, met alle gevolgen van dien. Ook de seksuele revolutie kan in dit kader worden verstaan.

\section{Plato}

In het tweede en derde hoofddeel komen Plato en het christendom aan de orde, Athene en Jeruzalem. Deze twee stromen hebben samen de grote Europese Traditie gevormd. Om een begrip te krijgen van Plato is het natuurlijk nodig iets te begrijpen van diens ideeënleer. We kunnen hier meer kennis van hebben dan van de stoffelijke wereld, omdat het stoffelijke voortdurend in beweging is en verandert. Daarom moet onze kennis gericht zijn op de orde onder de zintuiglijke chaos. Deze orde/idee is dus eigenlijk transcendent ten opzichte van de zichtbare werkelijkheid.

Kinneging maakt duidelijk dat de leer van de ideeën vooral moreel bepaald is. De morele crisis in de tijd van Plato bracht hem tot de ontwikkeling van een ontologisch begrip van het goede, ware en schone. Omdat het een ontologisch begrip is, is er ook sprake van een zekere participatie in het goede, ware en schone.

Hier komt het begrip MAAT uit de titel om de hoek kijken. Het is het grote geheim van ons leven om de maat te vinden en maat te houden. In alle dingen geldt een orde, de natuur van de dingen, en daar moeten we ons naar voegen. Hier zit gelijk een kritisch scharnierpunt naar de Moderniteit, omdat de mens niet de maat van de dingen kan zijn.

Deze klassieke traditie stelt het beginsel van vrijheid en gelijkheid onder kritiek. De ware vrijheid is geen ongebondenheid, maar een transformatie naar de natuur van de dingen. Zo gedragen we ons verstandig. Het verstand is dus niet de instrumentele kennis van de Verlichting, maar een inzicht in het wezen van de orde die ons draagt.

Hier komt ook de klassieke antropologie naar voren. De mens bestaat uit verstand, wilskracht en begeerten, in deze hiërarchische volgorde. De mens van de Verlichting gedraagt zich op het onderste niveau. De mens van de Romantiek steekt in bij de wilskracht, terwijl de klassieke mens zich laat leiden door het verstand in de rijke zin van het woord. Als het verstand onze wil en onze verlangens leidt, en als ons verstand wordt geleid door de Maat, zijn we een deugdzaam en gelukkig mens.

Dat betekent niet dat al onze verlangens worden vervuld. Misschien impliceert ons geluk wel een innerlijk conflict met onze begeerten. Misschien moeten we wel strijden tegen onze begeerte naar chocolade om gezond en gelukkig te zijn. Als de lichamelijke verlangens van eten en seksualiteit het voor het 
zeggen krijgen, richten we onszelf en elkaar te gronde. Andersom moeten we misschien lichamelijke oefeningen doen als we er geen zin in hebben. Vrijheid is dus niet dat we onze begeerten leidend laten zijn, maar dat we ons voegen naar de orde van de maat.

Deze benadering heeft ook politieke consequenties. De beste regeringsvorm is niet de democratie waarin de begeerten van het volk leidend zijn, maar de regering door de besten. Zoals we in de voetbalwereld en in de wetenschap ook selecteren op de besten, zo zouden we dat ook in de politiek moeten doen. We zouden moeten omzien naar degenen die hun temperament, hun ego en hun verlangens onder controle hebben. Alleen zij kunnen het volk leiden. Dit pleit voor aristocratie. De democratie is de op één na slechtste regeringsvorm. Alleen de tirannie is slechter.

\section{Christendom}

De tweede bron van de Europese Traditie is het christendom. Volgens Kinneging is dit nauwelijks te onderscheiden van Plato. In de eerste plaats omdat in het Nieuwe Testament al veel Plato aanwezig is. Ten tweede omdat Augustinus een platoons denker was en dit nader is uitgewerkt door Thomas van Aquino. Ten slotte omdat ook iemand als Luther - ondanks zijn heftige kritiek op Aristoteles - niet los was van deze klassieke traditie.

Het christendom stemt overeen met de klassieke traditie dat het hart van de mens niet deugt en dat dit uitkomt in de opvoeding. Ook het zondebesef kent een rijke gevoeligheid voor afwijkingen van de norm in de doordenking van hoogmoed, hebzucht, wellust, toorn, gulzigheid, afgunst en traagheid, de zogenaamde zeven hoofdzonden. Hier scharniert een belangrijke tegenstelling met de Moderniteit waar uiteindelijk het zondebegrip is verdwenen.

Kinneging ziet wel een verschil. In het christelijk geloof is er een dieper zondebegrip dan in de Griekse Oudheid. Dit hangt ermee samen dat de wet in het christendom meer verinnerlijkt is. Ook is de moraal sterker gestempeld door de plicht om het goede te doen. Het begrip van liefde gaat in het christendom ook dieper. Iemand als Augustinus heeft met zijn scheppingsbegrip ook veel radicaler laten zien dat de schepping geen deel uitmaakt van God. Bij Augustinus is er ook meer sensitiviteit voor het conflict tussen het eigenbelang en de intrinsieke motivatie om het goede te doen. Daarom is bij de kerkvader de wil belangrijker dan het verstand.

Bij Thomas van Aquino komen tal van aspecten uit de Griekse Oudheid en van Augustinus samen. Hij heeft de mensleer, de deugdenleer en de zondeleer van de Europese Traditie verder verfijnd. Een sprekend voorbeeld is zijn idee over homoseksualiteit. Terwijl voor een modern mens homoseksualiteit veel minder een probleem is dan verkrachting is het voor Thomas andersom, 
omdat verkrachting dichter bij de natuur blijft. Het is een symptoom dat in onze moderne cultuur de vrijwilligheid een belangrijk criterium is.

\section{Overwegingen}

We zeggen Kinneging dank voor een boek waarin hij de maat niet heeft gehouden... Er zitten ook wat uitweidingen en herhalingen in die wellicht weggelaten hadden kunnen worden. Er zijn ook tal van detailissues die van kritiek zouden kunnen worden voorzien, maar het lijkt mij wat flauw om daarop in te gaan om daarmee de boodschap van dit boek af te doen. Het boek van Kinneging helpt ons om aspecten van de hedendaagse cultuur te herkennen, te plaatsen en te peilen.

Toch heb ik vragen waarvan ik denk dat ze niet over detailkwesties gaan. In de eerste plaats is het mij niet duidelijk hoe Kinneging zich het vervolg voorstelt. Hij is er goed in om de kwalen van de hedendaagse cultuur onder de lamp van de Europese Traditie te leggen, maar hoe nu verder? De boekdrukkunst als facet van de Moderniteit kan op een positief onthaal rekenen. Antibiotica is ongeveer even oud als de doorbraak van Verlichting en Romantiek in de vorige eeuw. Als ik merk dat Kinneging positief is over de medische wetenschap van vandaag, betekent het dus niet dat hij de klok radicaal terug wil draaien. Toch wil hij de klok terugdraaien. Geldt dit dan alleen voor de moraal? Dat lijkt mij een belangrijk punt van de Leidse filosoof. Maar de politieke structuur zit hem ook niet lekker, evenmin als de stand van zaken in de academische wereld. Over de hedendaagse opvoeding heeft hij ook belangrijke vragen, evenals over het onmatig gebruik van grondstoffen. Of bedoelt hij de huidige wetenschappelijke kennis alleen als de minste trap van kennis te honoreren? Dat roept de vraag op of het eigenlijk wel mogelijk is om selectief te shoppen in de wereld na Verlichting en Romantiek. Over deze dilemma's had ik graag wat meer gelezen. Dus het boek had nog een maatje groter gemogen...

Hierachter zit voor mij een tweede complex van vragen: hoe had men in de Europese Traditie moeten reageren op de ontdekking van Copernicus dat de klassieke kosmologie niet klopte? Aangezien de kosmologie in die dagen tot het wezen van het geloof behoorde, was de ontdekking van Copernicus een existentiële. Als er aan de kosmologie werd gemorreld, werd er ook aan de moraal gemorreld en aan de mensleer. Descartes en later Kant stonden voor de vraag welke consequenties deze nieuwe ontdekkingen voor het wereldbeeld en voor het totale leven hadden. Kant bekritiseerde de Verlichting en wilde in zijn benadering ruimte laten voor het transcendente, het geloof en de moraal. Als Kinneging wat snerend schrijft dat Galilei en Newton de grote helden werden van de Moderniteit, roept dit wel de dringende vraag op hoe 
hij met het nieuwe wereldbeeld van Newton om wil gaan. Het gaat hier immers niet om detailkwesties, maar om de existentiële vraag in welke wereld wij leven.

De gemakkelijke claim van het platoonse denken voor het christendom gaat mij - ten derde - ook te snel. Is het christendom niet van een andere orde dan het wereldbeeld van Plato? Inderdaad kan het christendom elementen van Plato in zich opnemen. Het besef dat de Geest onder alle volkeren wijsheid leert, biedt daarvoor een theologisch kader. Maar de opgestane Christus komt niet uit de verf als het christendom als een variatie van het Griekse denken wordt gezien. Zit er dan toch niet meer in het conflict van Luther met de immanent denkende Aristoteles dan Kinneging voor waar wil hebben? Heeft het christendom anderzijds niet meer respect voor het lichamelijke dan Plato? Moeten we de zielsleer van Plato in het christelijk geloof vandaag overnemen of kan bijvoorbeeld de menselijke affectie in het christelijke geloof positief worden geduid? Zou het zo kunnen zijn dat elke cultuur nieuwe facetten aan het licht brengt die in het licht van de rijkdom van het katholieke geloof positief te waarderen zijn? Dit zou betekenen dat een actuele doordenking van het christelijke geloof tot een ander concept leidt dan een simpel herstel van de Europese Traditie.

\section{Tot slot}

Kinneging reikt ons een stuk gereedschap aan om een diagnose uit te voeren van onze eigen tijd en cultuur. De uitkomst valt niet mee. In zijn analyse van nihilisme en egocentrisme heeft hij gewoon gelijk. Het onderscheid tussen Verlichting en Romantiek is ook behulpzaam om de verschillende tendensen in onze huidige cultuur te kunnen onderscheiden. Dit betekent dat dit boek vanuit een christelijk perspectief vooral betekenis heeft voor de moraal. Zonder de ideeënleer van Plato over te nemen, helpt Plato ons wel bij het besef dat de moraal buiten deze wereld is verankerd en absoluut is. Op een bepaalde manier kunnen we ook wel wat met zijn deugdenleer. Het evenwicht van hoofd en hart, wil en geweten lijkt mij ook toepasbaar in de christelijke doordenking vandaag. Kortom: Kinneging helpt ons niet alleen onze eigen cultuur te duiden, maar hij daagt ons ook uit om over de verhouding christendom en cultuur na te denken en daar een constructieve bijdrage aan te leveren. 